\section{Anaesthesia for Caesarean section in a patient with acute fatty liver of pregnancy}

Joseph F. Antognini MD, Susan Andrews MD
A 23-yr-old woman presented in labour and hepatic failure. The clinical diagnosis was acute fatty liver of pregnancy. A Caesarean section was performed under epidural anaesthesia, after correction of a coagulopathy. Epidural anaesthesia was chosen because of the potential deleterious effects of general anaesthesia on liver blood flow and function.

Une femme de 23 ans en défaillance hépatique s'est présentée pour accouchement. Le diagnostic clinique était une stéatose hépatique aiguë de la grossesse. Une césarienne fut faite sous anesthésie épidurale après correction de sa coagulopathie. L'anesthésie épidurale fut choisie à cause des effets néfastes potentiels de l'anesthésie générale sur le flot sanguin hépatique et la fonction hépatique.

Jaundice and hepatic failure are rare events during pregnancy. Anaesthesia during hepatic failure is generally considered to be contraindicated except in the most life-threatening situations. ${ }^{1}$ We report here a patient for urgent Caesarean section who had hepatic failure secondary to acute fatty liver of pregnancy (AFLP).

\section{Case report}

This 23-yr-old $\mathrm{G}_{2} \mathrm{P}_{0}$ woman presented in acute hepatic failure at 38 wk gestation. She was well until one week before admission, when she developed general malaise with nausea. One day before admission, the nausea worsened and she had considerable vomiting and diarrhoea. At that time she also noted the onset of uterine

\section{Key words}

ANAESTHESIA: obstetric;

LIVER: disease.

From the Department of Anesthesiology, American River

Hospital, Carmichael, CA.

Address correspondence to: Dr. Joseph F. Antognini, Operating Room, American River Hospital, 4747 Engle Rd., Carmichael, CA 95608.

Accepted for publication 21st May, 1991. contractions and slight yellowing of her skin, but she did not have pruritus. She had no other complaints. Her past medical history was significant only for the diagnosis of Berger's disease seven years earlier, which was manifested by several episodes of asymptomatic haematuria. Biochemical evaluation six months before admission demonstrated normal blood urea nitrogen (BUN), creatinine and liver function tests.

On physical examination, she appeared ill and jaundiced and was in labour. Blood pressure (BP) was 110/74 $\mathrm{mmHg}$, temperature $36.6^{\circ} \mathrm{C}$, respirations 24 breaths per minute and heart rate 100 beats per minute (bpm). She was alert and oriented. The heart and lungs were normal. Abdominal examination revealed a 38 wk gestation pregnancy; the liver was not palpable and there was no right upper quadrant tenderness. She had no extremity or sacral oedema.

Laboratory tests demonstrated acute hepatic failure with a concomitant coagulopathy, renal insufficiency, mild hypoglycaemia, metabolic acidosis (Table) and proteinuria. The clinical diagnosis was AFLP and, because of decreased fetal heart rate variability, an urgent Caesarean section was planned. Initial treatment was intravenous hydration with $3 \mathrm{~L}$ lactated Ringer's solution over six hours. To correct the coagulopathy vitamin $\mathrm{K} 25$ mg was administered, along with two units fresh frozen plasma. During this time the BP had gradually increased to $160 / 100 \mathrm{mmHg}$.

After the placement of a radial arterial catheter the patient was taken to the operating room and $800 \mathrm{ml}$ lactated Ringer's solution were given. The $\mathrm{BP}$ was $165 / 105 \mathrm{mmHg}$, and heart rate was $145 \mathrm{bpm}$. An epidural catheter was placed at the $\mathrm{L}_{3}-\mathrm{L}_{4}$ interspace and $3 \mathrm{ml}$ lidocaine $2 \%$ with epinephrine $1: 200,000$ and $\mathrm{NaHCO}_{3}$ $0.1 \mathrm{mEq} \cdot \mathrm{ml}^{-1}$ were given without observable effect. An additional $15 \mathrm{ml}$ administered over several minutes resulted in a block to $T_{4}$. The patient was placed supine with left uterine displacement, and during the next $30 \mathrm{~min}$ the BP decreased to $120-130 / 60 \mathrm{mmHg}$. A viable male was born with Apgar scores of five at one minute and eight at five minutes. Epidural fentanyl, $50 \mu \mathrm{g}$, was given and the catheter was removed. Total blood loss was $800 \mathrm{ml}$, 
TABLE

\begin{tabular}{|c|c|c|c|c|c|}
\hline & Admission & Preop & $P O D 1$ & POD 2 & Normal \\
\hline $\mathrm{Na}^{+}\left(\mathrm{mEq} \cdot \mathrm{L}^{-1}\right)$ & 138 & - & 143 & 140 & $136-144$ \\
\hline $\mathrm{K}^{+}\left(\mathrm{mEq} \cdot \mathrm{L}^{-1}\right)$ & 3.7 & - & 4.1 & 4.6 & $3.4-5.3$ \\
\hline $\mathrm{Cl}^{-}\left(\mathrm{mEq} \cdot \mathrm{L}^{-1}\right)$ & 102 & - & 117 & 115 & $98-108$ \\
\hline $\mathrm{HCO}_{3}{ }^{-}\left(\mathrm{mEq} \cdot \mathrm{L}^{-1}\right)$ & 13 & - & 20 & 20 & $21-30$ \\
\hline $\mathrm{GLU}\left(\mathrm{mg} \cdot \mathrm{dl}^{-1}\right)$ & 60 & - & 106 & 90 & $70-110$ \\
\hline $\operatorname{BUN}\left(\mathrm{mg} \cdot \mathrm{dl}^{-1}\right)$ & 22 & - & 17 & 21 & $8-23$ \\
\hline $\mathrm{Cr}\left(\mathrm{mg} \cdot \mathrm{dl}^{-1}\right)$ & 3.0 & - & 2.4 & 2.2 & $0.4-1.3$ \\
\hline $\mathrm{UA}\left(\mathrm{mg} \cdot \mathrm{dl}^{-1}\right)$ & 10.4 & - & 9.2 & 6.7 & $2.4-5.7$ \\
\hline $\mathrm{TB}\left(\mathrm{mg} \cdot \mathrm{dl}^{-1}\right)$ & 11.4 & - & 11.8 & 14.3 & $0.0-1.0$ \\
\hline $\mathrm{AP}\left(\mathrm{IU} \cdot \mathrm{L}^{-1}\right)$ & 412 & - & 205 & 206 & $40-120$ \\
\hline $\operatorname{SGOT}\left(\mathrm{IU} \cdot \mathbf{L}^{-1}\right)$ & 393 & - & 141 & 65 & $0-37$ \\
\hline $\operatorname{SGPT}\left(\mathrm{IU} \cdot \mathrm{L}^{-1}\right)$ & 585 & - & 254 & 170 & $4-37$ \\
\hline $\mathrm{NH}_{3}\left(\mathrm{mg} \cdot \mathrm{dl}^{-1}\right)$ & & - & - & 112 & $5-70$ \\
\hline PT(sec) & 17.1 & 12.2 & 17.7 & 18.2 & $11-13$ \\
\hline PTT(sec) & 50.0 & 41.4 & 50.8 & 47.4 & $<43 \mathrm{sec}$ \\
\hline Bleeding time ( $\mathrm{min})$ & 3.5 & - & - & - & $2-8$ \\
\hline Hct & $47 \%$ & - & $32 \%$ & $36 \%$ & $37-47 \%$ \\
\hline $\mathrm{WBC} \cdot 10^{3} \cdot \mathrm{ml}^{-1}$ & 25 & - & 17 & 17 & $4.8-10.8$ \\
\hline \multirow[t]{2}{*}{ plts $\cdot 10^{3} \cdot \mathrm{ml}^{-1}$} & 166 & - & 81 & 79 & $150-400$ \\
\hline & Admission & & & & Normal \\
\hline ABG: & Room air & & & & \\
\hline $\mathrm{PO}_{2}$ & $117 \mathrm{mmHg}$ & & & & $>70$ \\
\hline $\mathrm{PCO}_{2}$ & $21 \mathrm{mmHg}$ & & & & $35-45$ \\
\hline $\mathrm{pH}$ & 7.26 & & & & $7.35-7.45$ \\
\hline $\mathrm{BE}$ & -15 & & & & \pm 2 \\
\hline Hptgbn & $11 \mathrm{mg} \cdot \mathrm{dl}^{-1}$ & & & & $13-163$ \\
\hline $\mathrm{Hgb}$ (free) & $9.3 \mathrm{mg} \cdot \mathrm{dl}^{-1}$ & & & & $0.0-5.0$ \\
\hline
\end{tabular}

$\mathrm{GLU}=$ glucose, $\mathrm{UA}=$ uric acid, $\mathrm{TB}=$ total bilirubin, $\mathrm{AP}=$ alkaline phosphatase, $\mathrm{SGOT}=$ serum glutamic-oxaloacetic trans-aminase , SGPT $=$ serum glutamic-pyruvic transaminase, $\mathrm{Hptgbn}=$ haptoglobin, plts $=$ platelets, $\mathrm{POD}=$ postoperative day .

and fluid replacement consisted of $1800 \mathrm{ml}$ lactated Ringer's and $500 \mathrm{ml}$ normal saline, and one unit of fresh frozen plasma was given in the recovery room.

Over the next $36 \mathrm{hr}$ the patient became lethargic and had increased bilirubin and ammonia and decreased transaminase concentrations. Because of the danger of fulminant hepatic failure, she was transferred to a facility capable of performing liver transplantation. However, she made a quick recovery over $48 \mathrm{hr}$. A liver biopsy confirmed the diagnosis of AFLP. She was subsequently discharged in excellent condition with no sequelae. Admission studies for acute and chronic viral hepatitis were negative.

\section{Discussion}

Jaundice during pregnancy has several causes, including AFLP, cholestasis, cholelithiasis, hyperemesis gravidarum, viral hepatitis and pre-eclampsia. ${ }^{2,3}$ The incidence of jaundice is about one in 1500 pregnancies, with cholesta- sis and viral hepatitis occurring most commonly. Traditionally, AFLP has been considered to be rare, with some authors assigning an incidence of one in one million pregnancies. ${ }^{4}$

Diagnosing the aetiology of jaundice during pregnancy is accomplished by a combination of clinical findings and laboratory examination. Acute fatty liver of pregnancy presents with a prodrome of malaise, nausea and vomiting, followed by jaundice within about a week. ${ }^{2}$ The clinical course is variable, ranging from primarily laboratory abnormalities to extensive hepatic failure, with concomitant renal failure, coma, metabolic acidosis, thrombocytopaenia, disseminated intravascular coagulation and death. ${ }^{2,3}$ Cholestasis usually presents with intense pruritus, and the bilirubin concentrations is rarely above $5 \mathrm{mg} \cdot \mathrm{dl}^{-1}$ Cholelithiasis during pregnancy is similar to the presentation in the non-pregnant state and hyperemesis gravidarum occurs during the first trimester. Viral hepatitis presents with extremely high transaminase 
levels, and the diagnosis is usually confirmed with a hepatitis screen. Liver dysfunction due to pre-eclampsia may manifest as only biochemical abnormalities but in severe cases may include fulminant disseminated intravascular coagulation, thrombocytopaenia, epigastric pain and liver haemorrhage. Although our patient did not strictly meet the criteria for pre-eclampsia, she did have hypertension and proteinuria. In addition, she had evidence of haemolysis, with elevated free haemoglobin and decreased haptoglobin concentrations.

The diagnosis of AFLP is confirmed by liver biopsy, although a coagulopathy may preclude this procedure. A CT scan may also be useful in establishing the diagnosis, since it will reveal the typical low density changes that occur with fatty infiltration of the liver. Treatment of AFLP consists of early recognition, delivery of the fetus, and supportive care.

To our knowledge, this is the first case report of anaesthesia in a patient with AFLP. Although there have been at least two published series of AFLP, ${ }^{5,6}$ with some of the patients having a Caesarean section, the anaesthetic management was not described. These authors also believed that the incidence of AFLP was much higher than originally thought, because of a possible link between pre-eclampsia and AFLP. Thus, there may be a continuum between pre-eclampsia and AFLP, including the HELLP syndrome (Haemolysis, Elevated Liver enzymes and Low Platelets).

Anaesthesia and surgery in patients with acute and chronic liver disease carry considerable risks, particularly if hepatitis is present. Powell-Jackson et al. ${ }^{7}$ described 36 patients with unrecognized liver disease who had exploratory laparotomy. The overall mortality was $31 \%$, and all those with hepatitis died. Patients with advanced cirrhosis also have considerable risks with surgery: $67 \%$ of patients in one series died after laparotomy. ${ }^{8}$ The exact contribution of anaesthesia to this increased risk is uncertain, since intra-abdominal surgery per se has been shown to decrease liver blood flow. ${ }^{9}$ The effect of Caesarean section on liver blood flow is unknown.

Epidural anaesthesia was chosen in our patient primarily because of the potential deterioration in liver function and liver blood flow that may occur with general anaesthesia. For example, controlled ventilation, ${ }^{10}$ inhalational anaesthetics and surgical stress ${ }^{11}$ can decrease liver blood flow. Regional anaesthesia probably preserves liver blood flow as long as normotension is maintained. ${ }^{12}$ Since the stress response during surgery is reduced with regional anaesthesia, ${ }^{13}$ and catecholamines decrease liver blood flow, epidural anaesthesia might be superior to general anaesthesia in this regard. The rare potential hepatotoxicity associated with the inhalational anaesthetics also makes regional anaesthesia more attractive.
The effect of thiopentone and other intravenous agents on liver blood flow is not well established, as some studies demonstrate no changes in liver circulation, while others have shown a decrease in liver blood flow. ${ }^{11}$ Likewise, the effects of $\mathrm{N}_{2} \mathrm{O}$ are controversial, but in general, liver blood flow is probably decreased. ${ }^{11}$ Isoflurane would be the most logical choice for a potent inhalational anaesthetic, since it has little or no hepatotoxicity, and may preserve liver blood flow, ${ }^{14}$ although this is controversial. ${ }^{15}$ In addition, drug metabolism might be altered in AFLP, so that general anaesthetic agents, e.g., thiopentone, could have a longer effect. Despite these disadvantages, if general anaesthesia is chosen, thiopentone in small doses, $\mathrm{N}_{2} \mathrm{O}$ and isoflurane are reasonable choices.

Regional anaesthesia in the presence of a coagulopathy that accompanies AFLP increases the risk of an epidural haematoma. Recognition and treatment of thrombocytopaenia and deficient clotting factors is essential prior to regional anaesthesia. Since such a coagulopathy would be an evolving process, any corrective measures are likely to be temporary, as occurred in our patient.

In summary, this patient presented in labour with acute hepatic failure secondary to AFLP. Because of fetal compromise, a Caesarean section was planned, and after correcting her coagulopathy, epidural anaesthesia was chosen because of the possible deleterious effects of general anaesthesia on liver blood flow and function.

\section{References}

1 McCammon RL. Diseases of the liver and biliary tract. In: Stoelting RK, Dierdorf SF (Eds.). Anesthesia and Co-existing Disease. New York: Churchill Livingstone, 1983; 347-8.

2 Sherlock $S$. Diseases of the Liver and Biliary System. Oxford: Blackwell Scientific Publications, 1985; 420-8.

3 Krejs GJ, Haemmerli UP. Miscellaneous disorders. In: Schiff L, Schiff ER (Eds.). Diseases of the Liver. Philadelphia: JB Lippincott, 1982; 1561-80.

4 Samuels $P$, Landon MB. Medical complications. In: Gabbe SG, Niebyl JR, Simpson JL (Eds.). Obstetrics: Normal and Problem Pregnancies. New York: ChurchillLivingstone, 1986; 938-9.

5 Reily CA, Latham PS, Romero R, Duffy TP. Acute fatty liver of pregnancy. Ann Int Med 1987; 106; 703-6.

6 Burroughs AK, Seong NH, Dojcinov DM, Scheuer PJ, Sherlock SVP. Idiopathic acute fatty liver of pregnancy in 12 patients. Q J Med 1982; 51: 481-97.

7 Powell-Jackson P, Greenway B, Williams R. Adverse effects of exploratory laparotomy in patients with unsuspected liver disease. Br J Surg 1982; 69: 449-51.

8 Aranha $G V$, Greenlee $H B$. Intra-abdominal surgery in patients with advanced cirrhosis. Arch Surg 1986; 121: 275-7. 
9 Gelman SI. Disturbances in hepatic blood flow during anesthesia and surgery. Arch Surg 1976; 111: 881-3.

10 Cooperman LH, Warden JC, Price HL. Splanchnic circulation during nitrous oxide anesthesia and hypocarbia in normal man. Anesthesiology 1968; 29: 254-8.

11 Gelman $S$. General anesthesia and hepatic circulation. Can J Physiol Pharmacol 1987; 65: 1762-79.

12 Runciman WB, Mather LE, Ilsley AH, Carapetis RJ, Upton $R N$. A sheep preparation for studying interactions between blood flow and drug disposition. III: Effects of general and spinal anaesthesia on regional blood flow and oxygen tensions. Br J Anaesth 1984; 56: 1247-58.

13 Kehlet $H$. Modification of responses to surgery by neural blockade: clinical implications. In: Cousins MJ, Bridenbaugh PO (Eds.). Neural Blockade in Clinical Anesthesia and Management of Pain, Philadelphia: JB Lippincott, 1988; 145-88.

14 Goldfarb G, Debaene B, Ang ET, Roulot D, Jolis $P$, Lebrec $D$. Hepatic blood flow in humans during isoflurane $\mathrm{N}_{2} \mathrm{O}$ and halothane- $\mathrm{N}_{2} \mathrm{O}$ anesthesia. Anesth Analg 1990; 71: 349-53.

15 Conzen PF, Hobbhahn J, Goetz AE et al. Splanchnic oxygen consumption and hepatic surface oxygen tensions during isoflurane anesthesia. Anesthesiology 1988; 69: 643-51. 